\title{
Properties of a DNA polymerase from purified nuclei and DNA-synthesizing complexes of human spermatozoa
}

\author{
S. S. Witkin \\ Memorial Sloan-Kettering Cancer Center, 1275 York Avenue, New York, New York 10021, \\ U.S.A.
}

\begin{abstract}
Summary. A DNA polymerase was isolated from human spermatozoa. In one procedure, spermatozoa were decapitated with detergent, the heads purified and then lysed with dithiothreitol, trypsin and deoxyribonuclease. DNA polymerase was isolated from the lysate by sedimentation through an $18 \%$ Metrizamide solution, solubilization with $0.8 \mathrm{M}-\mathrm{KCl}-0.5 \%$ Triton $\mathrm{X}-100$ and sequential chromatography on DEAE cellulose, phosphocellulose and hydroxylapatite. Alternatively, the heads of intact spermatozoa, untreated with detergent, were lysed as above; the subsequent Metrizamide pellet fraction was isolated and further fractionated by gel filtration and buoyant density centrifugation. The enzyme in this fraction was solubilized with $\mathrm{KCl}-$ Triton $\mathrm{X}-100$. Characterization by velocity centrifugation and phosphocellulose chromatography revealed that it possessed properties indistinguishable from those of the enzyme purified from isolated sperm nuclei. The DNA polymerase had an apparent molecular weight of $79000-89000, \mathrm{Mn}^{2+}(1 \mathrm{mM})$ was the preferred divalent cation and activity was inhibited by concentrations of potassium phosphate greater than $10 \mathrm{~mm}$. The synthetic template preferences of the enzyme were $\mathrm{dT}_{12-18} \cdot$ poly $\mathrm{rA}>$ poly $(\mathrm{dA}-\mathrm{dT})>\mathrm{dT}_{12-18} \cdot$ poly $\mathrm{dA}$; no activity was observed with $\mathrm{dG}_{12-18} \cdot$ poly $\mathrm{rC}$ or $\mathrm{dT}_{10}$.
\end{abstract}

\section{Introduction}

DNA-synthesizing complexes appear to be normal components of human spermatozoa. Liberated from sperm nuclei following their decondensation with dithiothreitol, these complexes were capable of the polymerization of $\left[{ }^{3} \mathrm{H}\right]$ TTP (Witkin, Korngold \& Bendich, 1975) or $\left[{ }^{3} \mathrm{H}\right] \mathrm{dCTP}$ (Bendich, Borenfreund, Witkin, Beju \& Higgins, 1976) into acid-insoluble polymers in the absence of an exogenously supplied template. Analysis of the ${ }^{3} \mathrm{H}$-labelled producttemplate complex revealed that RNA was probably serving as both template and primer for the synthesis of DNA (Witkin \& Bendich, 1977).

An antiserum inhibitory to the DNA polymerase component of the complex was elicited in a rabbit by immunization (Witkin \& Higgins, 1978) with purified human sperm nuclei (Witkin, Evenson \& Bendich, 1977b). The immunoglobulin G (IgG) fraction of this antiserum inhibited the activity of DNA polymerases partly purified from human spermatozoa and seminal fluid, as well as the reverse transcriptase (RNA-instructed DNA polymerase) of the non-oncogenic C-type baboon endogenous retrovirus (BEV) and the feline virus, $\mathrm{RD} 114$. Other type $\mathrm{C}$ viral reverse transcriptases were unaffected (Witkin, Higgins \& Bendich, 1978). In addition, IgG purified from sera of some individual male and female members of infertile marriages also inhibited the sperm-derived DNA polymerase, suggesting that the enzyme was auto-antigenic. Further studies have demonstrated that one facet of the auto-immunological consequences of 
vasectomy was the production of $\mathrm{IgG}$ inhibitory to the seminal fluid DNA polymerase (Higgins, Witkin \& Bendich, 1978), possibly because of the formation of antibodies to the sperm enzyme.

We have now analysed the properties of a DNA polymerase isolated from purified human sperm heads or the DNA-synthesizing complexes obtained from whole spermatozoa.

\section{Materials and Methods}

Semen was obtained from medical and graduate student donors. Following liquefaction at room temperature, the ejaculates were mixed with an equal volume of glycerol for storage at $-20^{\circ} \mathrm{C}$.

\section{DNA polymerase purification from sperm nuclei}

In a typical experiment, 5-20 ejaculates of a single donor (about $2 \times 10^{8}$ spermatozoa/ ejaculate) were utilized. The samples were thawed, pooled and diluted with 3 volumes of TNE buffer $(0.01 \mathrm{M}$-Tris- $\mathrm{HCl}, \mathrm{pH} 7.5,0.15 \mathrm{M}-\mathrm{NaCl}, 1 \mathrm{~mm}$-EDTA). All subsequent steps were at $0-4^{\circ} \mathrm{C}$, unless otherwise noted. Spermatozoa were concentrated by centrifugation at $1500 \mathrm{~g}$ for $10 \mathrm{~min}$, resuspended in TNE buffer and recentrifuged for 3 additional cycles to remove seminal plasma constituents. The final sperm pellet was suspended in $0.05 \mathrm{M}$-Tris- $\mathrm{HCl}, \mathrm{pH} 7 \cdot 5$, to give $0.4 \mathrm{ml} /$ ejaculate, and sodium lauroyl sarcosinate (Sarkosyl: Chemical Additives Co., Farmingville, New York) was added to a final concentration of $1.5 \%$. Treatment with Sarkosyl decapitates mammalian spermatozoa (Gall, Millette \& Edelman, 1975; Witkin et al., 1977b) and removes the plasma, acrosomal and nuclear membranes (Witkin et al., 1977b). It has been our experience that spermatozoa stored at $-20^{\circ} \mathrm{C}$ were more resistant to this treatment than were those in freshly obtained ejaculates. However, about $98 \%$ of the spermatozoa were cleaved by vigorously mixing the spermatozoa-Sarkosyl suspension for $30 \mathrm{sec}$ in a Vortex mixer (Scientific Industries Inc., Queensville, New York) followed by incubation at $37^{\circ} \mathrm{C}$; separation of heads from tails was usually complete by $15 \mathrm{~min}$.

Detached sperm heads were purified according to the procedure of Calvin (1976). The suspension was brought to $9.5 \mathrm{ml}$ with $1.6 \mathrm{M}$-sucrose in $0.01 \mathrm{M}$-Tris- $\mathrm{HCl}, \mathrm{pH} 7.5,2 \mathrm{mM}$-EDTA and layered onto a discontinuous gradient of $10.5 \mathrm{ml} 2.2$ M-sucrose and $10.5 \mathrm{ml} 2.05$ M-sucrose, both in the same Tris-EDTA buffer as the sample. Following centrifugation for 60 min at $51000 \mathrm{~g}$, sperm heads were recoverable in the pellet; the level of contamination with tails was consistently $<2 \%$. The heads were resuspended $(0.2 \mathrm{ml}$ ejaculate $)$ in $0.05 \mathrm{M}$-Tris $-\mathrm{HCl}, 0.02$ M-dithiothreitol, plus $100 \mu \mathrm{g}$ trypsin/ml (Worthington Biochemical, Freehold, New Jersey) and incubated at $37^{\circ} \mathrm{C}$ until the heads lysed and the solution became highly viscous; this usually required 10-15 min. Pancreatic trypsin inhibitor (Trasylol: Mobay Chemical Co., New York) was then added at 200 units/ml to inhibit the activity of the added trypsin. The released DNA was degraded by the addition of $5 \mathrm{mM}-\mathrm{MgCl}_{2}$ and $20 \mu \mathrm{g}$ deoxyribonuclease $/ \mathrm{ml}$ (Worthington) followed by incubation at $37^{\circ} \mathrm{C}$ for $15 \mathrm{~min}$. A second deoxyribonuclease treatment was usually found to be essential in order to avoid the occurrence of multiple peaks on subsequent ion-exchange chromatographic steps. The disrupted sperm head mixture was clarified by centrifugation at $16000 \mathrm{~g}$ for $20 \mathrm{~min}$ and the DNA polymerase activity was concentrated from the resultant supernatant by sedimentation at $165000 \mathrm{~g}$ for $60 \mathrm{~min}$ through a solution of $18 \%$ (w/v) Metrizamide (Accurate Chemical and Scientific Corp., Hicksville, New York), as previously described (Witkin, Traganos \& Bendich, 1977a).

The Metrizamide pellet fraction was suspended in $1.0 \mathrm{ml} 0.1 \mathrm{M}$-Tris- $\mathrm{HCl}$, pH 7.6, 0.8 $\mathrm{M}-\mathrm{KCl}, 0.5 \%$ Triton X-100, $5 \mathrm{~mm}$-dithiothreitol and 200 units Trasylol and incubated for 30 min at $0^{\circ} \mathrm{C}$ to solubilize the proteins in the DNA polymerase complex. The addition of Trasylol at this and at subsequent stages of enzyme purification resulted in increased enzyme activity. The solution was diluted 40 -fold with Buffer D $(0.05 \mathrm{M}$-Tris- $\mathrm{HCl}, \mathrm{pH} 7.5,10 \%$ glycerol, 2 
mM-dithiothreitol) and loaded onto a $40 \mathrm{ml}$ column of DEAE cellulose (DE 52, Whatman Ltd., Maidstone, Kent, England) which had been previously equilibrated with $0.02 \mathrm{M}-\mathrm{KCl}$ in Buffer D. Two column volumes of $0.02 \mathrm{M}-\mathrm{KCl}$ in Buffer $\mathrm{D}$ were passed through the column and DNA polymerase was eluted by raising the $\mathrm{KCl}$ concentration to $0.4 \mathrm{M}$. Fractions were collected and assayed for $\mathrm{dT}_{12-18}$. poly rA-templated DNA polymerase activity, as described below.

The peak activity fractions from DEAE cellulose were pooled and Trasylol was added to 200 units $/ \mathrm{ml}$. The solution was diluted to $0.05 \mathrm{M}-\mathrm{KCl}$ with Buffer D and loaded onto a $40 \mathrm{ml}$ column of phosphocellulose (P11: Whatman), prepared as described by Burgess (1969), previously equilibrated with $0.05 \mathrm{M}-\mathrm{KCl}$ in Buffer $\mathrm{D}$. After washing with 2 column volumes of $0.05 \mathrm{M}-\mathrm{KCl}$ in Buffer D, DNA polymerase was eluted with a $200 \mathrm{ml} 0.05-0.7 \mathrm{M}-\mathrm{KCl}$ gradient in Buffer D.

The peak $\mathrm{dT}_{12-18} \cdot$ poly $\mathrm{rA}$ activity fractions from phosphocellulose were pooled, Trasylol was added to 200 units $/ \mathrm{ml}$ and the solution was dialysed for $16 \mathrm{~h}$ against 1 litre of 0.05

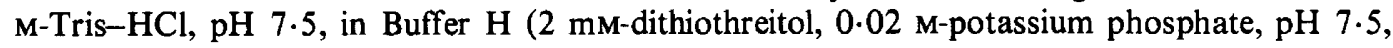
$20 \%$ glycerol). The solution was then layered onto a $20 \mathrm{ml}$ column of hydroxylapatite (Sphero-hydroxylapatite: Accurate Chemical and Scientific Corp., prepared according to the manufacturer), previously equilibrated with Buffer $\mathrm{H}$. After passing 2 column volumes of Buffer $\mathrm{H}$ through the column, DNA polymerase was eluted with an $0.02-0.3 \mathrm{M}$-potassium phosphate gradient in Buffer $\mathrm{H}$. The peak activity fractions were pooled and either utilized immediately or stored at $-70^{\circ} \mathrm{C}$.

Molecular weights were estimated by the method of Martin \& Ames (1961). Aliquots of the DNA polymerase were layered onto $10-30 \%(\mathrm{v} / \mathrm{v})$ glycerol or $15-30 \%(\mathrm{w} / \mathrm{w})$ sucrose gradients in $0.1 \mathrm{M}$-Tris- $\mathrm{HCl}, \mathrm{pH} 7.5,0.4 \mathrm{M}-\mathrm{KCl}, 5 \mathrm{~mm}$-dithiothreitol, subjected to centrifugation at $130000 \mathrm{~g}$ for $16 \mathrm{~h}$, fractionated and assayed for $\mathrm{dT}_{12-18}$. poly rA templated DNA polymerase activity. Human IgG, bovine serum albumin and sperm whale myoglobin were run as molecular weight markers in parallel gradients and located by absorbance at $280 \mathrm{~nm}$.

\section{Purification of intact DNA-synthesizing complexes}

We have previously devised a procedure of liberating the DNA-synthesizing complex from spermatozoa which does not involve pre-treatment with detergent (Witkin et al., 1977a). Briefly, whole spermatozoa, following 3 cycles of centrifugation and suspension in TNE buffer, were treated with dithiothreitol, trypsin and deoxyribonuclease as described above for purified sperm heads. This treatment resulted in complete sperm head lysis, while the tails remained intact as viewed by phase-contrast microscopy. A $165000 \mathrm{~g}$ Metrizamide pellet was obtained (see above), suspended in TNE buffer and subjected to gel filtration through an $80 \mathrm{ml}$ column of Ultrogel AcA 34 (20000-350 000 effective mol. wt range: LKB Instruments Inc., Rockville, Maryland). Fractions were eluted with TNE buffer and assayed for $\mathrm{dT}_{12-18} \cdot$ poly $\mathrm{rA}$-templated DNA polymerase activity (see below). The peak activity fractions, present in the void volume, were pooled and layered onto a $20 \mathrm{ml} 25-50 \%(\mathrm{w} / \mathrm{w})$ sucrose gradient in TNE buffer. After centrifugation at $165000 \mathrm{~g}$ for $16 \mathrm{~h}$ fractions were collected, their density determined from refractive indices, and aliquots assayed for $\mathrm{dT}_{12-18} \cdot$ poly rA-templated activity.

\section{DNA polymerase assays}

DNA polymerase activity was detected by measuring the polymerization of $\left[{ }^{3} \mathrm{H}\right] \mathrm{TTP}$ or $\left[{ }^{3} \mathrm{H}\right] \mathrm{dGTP}$ (New England Nuclear, Boston, Massachusetts) in the presence of the synthetic template-primers $\mathrm{dT}_{12-18} \cdot$ poly $\mathrm{rA}, \mathrm{dT}_{12-18} \cdot$ poly dA, $(\mathrm{dA}-\mathrm{dT}), \mathrm{dT}_{10}$ or $\mathrm{dG}_{12-18} \cdot$ poly $\mathrm{rC}(\mathrm{P}-\mathrm{L}$ Biochemical, Milwaukee, Wisconsin). In a final volume of $50 \mu$ l the reactions contained $0.5 \mu \mathrm{mol}$ dithiothreitol, $5 \mu \mathrm{g}$ bovine serum albumin, $0.05 \mu \mathrm{mol} \mathrm{MnCl}_{2}, 0.08 \mu \mathrm{mol}$ Tris $-\mathrm{HCl}, \mathrm{pH}$ $7.5,0.75 \mu \mathrm{g}$ synthetic template-primer and either $4 \mathrm{nmol}$ dTTP plus $5 \mu \mathrm{Ci}\left[{ }^{3} \mathrm{H}\right] \mathrm{TTP}$ (final sp. 
act. 770 c.p.m./pmol) or $4 \mathrm{nmol}$ dGTP plus $5 \mu \mathrm{Ci}\left[{ }^{3} \mathrm{H}\right] \mathrm{dGTP}$ (final sp. act. 685 c.p.m./pmol); $4 \mathrm{nmol} \mathrm{dATP}$ were also added to this mixture in poly $(\mathrm{dA}-\mathrm{dT})$-templated reactions. Incubation was at $30^{\circ} \mathrm{C}$ for the times indicated in the individual experiments. When measuring DNA polymerase activity in the DNA-synthesizing complex before it was solubilized with $0.1 \%$ Triton X-100 and $0.8 \mathrm{M}-\mathrm{HCl}, 0.1 \%$ Triton X-100 was included in the assay mixture. Reactions were terminated with $5 \%$ trichloroacetic acid-1\% sodium pyrophosphate and acid-insoluble radioactivity was measured (counting error less than $\pm 4 \%$ ) as described previously (Witkin et al., 1975). Assays run in the absence of added enzyme served as controls and the amount of acid-insoluble radioactivity present in these samples (300-600 c.p.m.) has been subtracted from the experimental values.

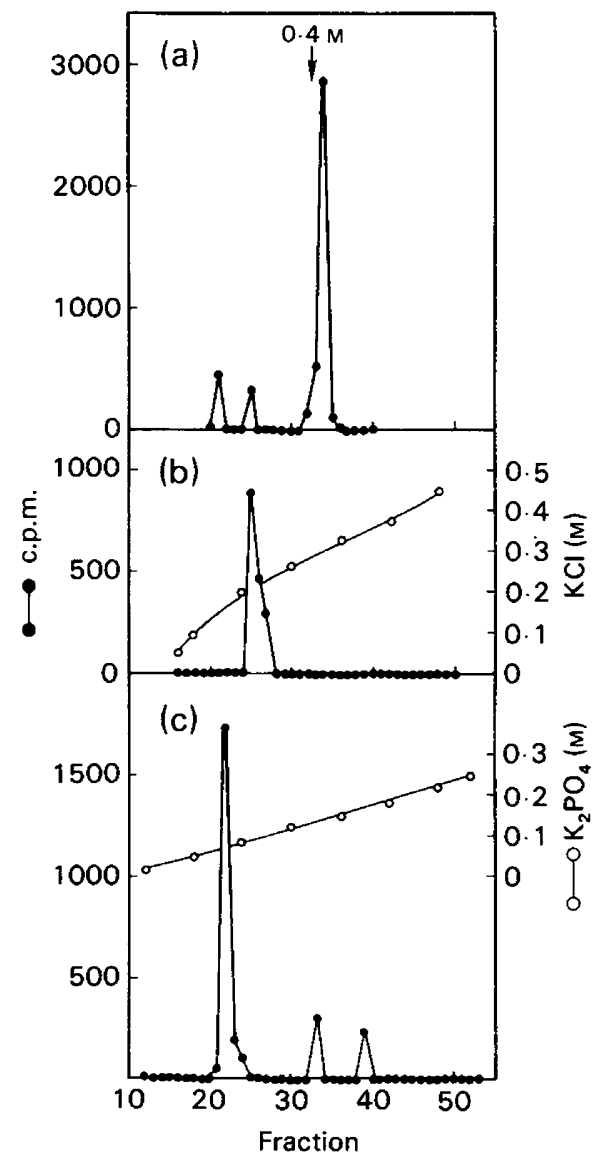

Text-fig. 1. Chromatography of human sperm DNA polymerase on (a) DEAE-cellulose, (b) phosphocellulose and (c) hydroxylapatite columns. (a) A $165000 \mathrm{~g}$ pellet fraction isolated from human sperm nuclei was treated with $0.8 \mathrm{M}-\mathrm{KCl}, 0.5 \%$ Triton $\mathrm{X}-1000$ and the solubilized enzyme was chromatographed on a $7.5 \times 2.6 \mathrm{~cm}$ column. Elution was with $0.4 \mathrm{M}-\mathrm{KCl}$. From each fraction $(0.5 \mathrm{ml}) 20 \mu \mathrm{l}$ were assayed using a dT $\mathrm{T}_{12-18}$. poly rA template. The arrow marks the start of the $0.4 \mathrm{M}-\mathrm{KCl}$ elution. (b) The pooled peak activity fractions from (a) were diluted and chromatographed on an $8.5 \mathrm{~cm}$ column. Elution was with $200 \mathrm{ml} 0.05-0.5 \mathrm{M}-\mathrm{KCl}$ gradient. Fractions $(1.95 \mathrm{ml})$ were collected and $20 \mu \mathrm{ll}$ aliquots were assayed for $\mathrm{dT}_{12-18} \cdot$ poly rA-templated activity. (c) The pooled peak activity fractions from (b) were dialysed and chromatographed on a $10.2 \times 1.5 \mathrm{~cm}$ column. Elution was with $40 \mathrm{ml} 0.02-0.3 \mathrm{M}-\mathrm{KPO}_{4}$ gradient. Aliquots $(20 \mu \mathrm{l})$ of each $1.0 \mathrm{ml}$ fraction were assayed for $\mathrm{dT}_{12-18} \cdot$ poly rA activity. 


\section{Results}

\section{DNA polymerase purification from sperm nuclei}

As shown in Text-fig. 1(a), most of the activity on DEAE-cellulose was coincident with the elution of $0.4 \mathrm{M}-\mathrm{KCl}$. The small amounts of $\mathrm{dT}_{12-18} \cdot \mathrm{rA}$ activity which preceded this main peak were not directly examined further. However, no additional DNA polymerase peaks were detected when either the $0.4 \mathrm{M}-\mathrm{KCl} \mathrm{DEAE}$-cellulose eluant or the fractions obtained by resuspending the $165000 \mathrm{~g}$ pellet in $0.4 \mathrm{M}-\mathrm{KCl}$ and passing it through the DEAE column were chromatographed on phosphocellulose.

When the pooled DNA polymerase-containing fractions from DEAE-cellulose were chromatographed on phosphocellulose with a $0.05-0.5 \mathrm{M}-\mathrm{KCl}$ gradient, there was one major peak of $\mathrm{dT}_{12-18}$. poly rA-templated enzyme activity, eluting at about $0.2 \mathrm{M}-\mathrm{KCl}$ (Text-fig. $1 \mathrm{~b}$ ).

Further elution on an hydroxylapatite column with a $0.02-0.3 \mathrm{M}$-potassium phosphate gradient gave one major peak of enzyme activity, eluting at 0.07 M-potassium phosphate (Text-fig. 1c). The other 2 fractions with minor activity were not studied further.

Results of a typical fractionation are summarized in Table 1. Starting from the DEAE-cellulose pool, a 25 -fold purification of the enzyme was accomplished with a $57 \%$ recovery. It was not possible to demonstrate a proportionality between enzyme activity and enzyme concentration at stages before the DEAE cellulose fraction, perhaps because of the continued presence of residual deoxyribonuclease, trypsin or seminal phosphatase. Activity was related to enzyme concentration at subsequent stages (data not shown).

Table 1. Purification of DNA polymerase from human sperm nuclei

\begin{tabular}{llccc}
\hline \multicolumn{1}{c}{ Fraction } & $\begin{array}{c}\text { Protein } \\
(\mathrm{mg})\end{array}$ & $\begin{array}{c}\text { Activity } \\
(\mathrm{pmol})\end{array}$ & $\begin{array}{c}\text { Recovery } \\
(\%)\end{array}$ & $\begin{array}{c}\text { Sp. act. } \\
(\mathrm{pmol} / \mathrm{mg})\end{array}$ \\
\hline Metrizamide pellet & 8.8 & - & & - \\
DEAE-Cellulose pool & 4.3 & 218.5 & 100 & $50 \cdot 8$ \\
Phosphocellulose pool & 1.4 & 210.2 & 96.2 & $150 \cdot 1$ \\
Hydroxylapatite pool & 0.09 & 125.3 & 57.3 & $1392 \cdot 2$ \\
\hline
\end{tabular}

\section{Properties of the sperm DNA polymerase}

A molecular weight estimation of the sperm DNA polymerase was obtained by subjecting the enzyme, purified through either the phosphocellulose or hydroxylapatite steps, to velocity sedimentation in a $10-30 \%$ glycerol, $0.4 \mathrm{M}-\mathrm{KCl}$ gradient and ascertaining the position of $\mathrm{dT}_{12-18} \cdot$ poly rA-templated activity relative to bovine serum albumin (68000). Assuming a globular protein, the sperm DNA polymerase was calculated to have a molecular weight of $79000-89000$, based on 3 separate experiments using the phosphocellulose- or hydroxylapatite-purified enzyme from 3 semen samples of individual donors. A typical profica is shown in Text-fig. 2. The more rapidly sedimenting shoulder was usually present (see also Text-fig. $4 \mathrm{a}$ ) and may represent an enzyme aggregate.

The preferred divalent cation for the $\mathrm{dT}_{12-18} \cdot$ poly $\mathrm{rA}$-templated reaction was $\mathrm{Mn}^{2+}$ with an optimum at $1 \mathrm{~mm}$; substitution of $\mathrm{Mg}^{2+}$ at its optimal concentration of $2 \mathrm{~mm}$ resulted in 5-fold less activity (Table 2). The enzyme was not inhibited by $0.01 \mathrm{M}$-potassium phosphate but phosphate concentrations of $0.02 \mathrm{M}$ and above were progressively inhibitory (Table 2).

The synthetic template-primer preferences of the purified sperm DNA polymerase are shown in Table 3. For comparison, values obtained with substitution of bovine DNA polymerase $\gamma$ (Worthington Biochemical) for the sperm enzyme are also given. The preferred template for both enzymes was $\mathrm{dT}_{12-18} \cdot$ poly $\mathrm{rA}$; substitution of $\mathrm{dT}_{12-18} \cdot$ poly $\mathrm{dA}$ led to a 4-fold (sperm enzyme) or 7 -fold (DNA polymerase $\gamma$ ) decrease in activity. The sperm enzyme was more effective than 


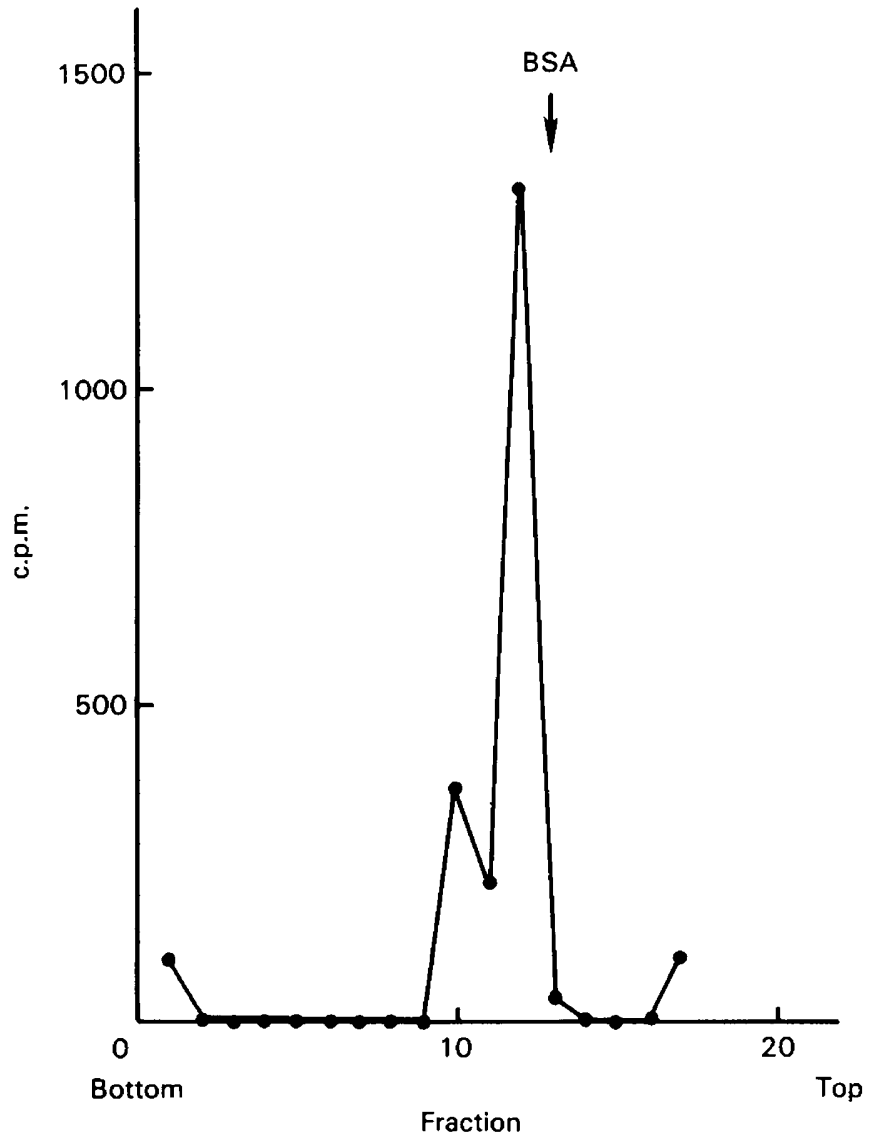

Text fig. 2. Velocity centrifugation of human sperm DNA polymerase. An aliquot $(0.2 \mathrm{ml})$ of the peak activity fraction from phosphocellulose was diluted with $0.1 \mathrm{ml}$ gradient buffer (see 'Materials and Methods') and sedimented in a $10-30 \%$ glycerol gradient. Aliquots $(20 \mu \mathrm{l})$ of each $0.3 \mathrm{ml}$ fraction were assayed using a $\mathrm{dT}_{12-18} \cdot$ poly $\mathrm{rA}$ template. The arrow marks the position of bovine serum albumin (mol. wt 68000 ) run in a parallel gradient.

the bovine enzyme in poly $(\mathrm{dA}-\mathrm{dT})$-templated reactions. Neither enzyme efficiently utilized $\mathrm{dT}_{10}$ or $\mathrm{dG}_{12-18} \cdot$ poly rC.

\section{Isolation of DNA-synthesizing complex}

A single major peak was obtained (Text-fig. 3a) in gel filtration fractions corresponding to the void volume (determined using blue dextran). Endogenous activity consistently co-eluted in these same fractions (data not shown). After equilibrium centrifugation in a sucrose gradient, peak activity was found at a density of $1.19 \mathrm{~g} / \mathrm{ml}$ (Text-fig. 3b), corresponding with our previously reported density for endogenous activity (Witkin et al., 1977a).

\section{Characterization of the DNA polymerase in the DNA-synthesizing complex}

The size of the enzyme in the $1.19 \mathrm{~g} / \mathrm{ml}$ density fraction was estimated by velocity sedimentation in a $10-30 \%$ sucrose gradient. There was a major peak in a fraction corresponding to a protein of 79000 molecular weight, and this peak and its shoulder (Text-fig. 4a) were similar 
Table 2. Effect of $\mathrm{PO}_{4}{ }^{-3}, \mathrm{Mg}^{2+}$ and $\mathrm{Mn}^{2+}$ on human sperm DNA polymerase

\begin{tabular}{|c|c|c|c|}
\hline Exp. & Addition & Conc. (mM) & $\begin{array}{l}\text { Incorporation } \\
\left(\text { pmol }\left[{ }^{3} \mathrm{H}\right] \mathrm{TTP}\right)\end{array}$ \\
\hline I & $\begin{array}{l}\text { None } \\
\mathrm{K}_{3} \mathrm{PO}_{4} \\
\mathrm{~K}_{3} \mathrm{PO}_{4} \\
\mathrm{~K}_{3} \mathrm{PO}_{4} \\
\mathrm{~K}_{3} \mathrm{PO}_{4} \\
\mathrm{~K}_{3} \mathrm{PO}_{4}\end{array}$ & $\begin{array}{r}- \\
10 \\
20 \\
30 \\
50 \\
100\end{array}$ & $\begin{array}{l}2.3 \\
2.6 \\
1.8 \\
1.8 \\
0.9 \\
0.8\end{array}$ \\
\hline II & $\begin{array}{l}\mathrm{None} \\
\mathrm{MnCl}_{2} \\
\mathrm{MnCl}_{2} \\
\mathrm{MnCl}_{2} \\
\mathrm{MnCl}_{2} \\
\mathrm{MnCl}_{2} \\
\mathrm{MgCl}_{2} \\
\mathrm{MgCl}_{2} \\
\mathrm{MgCl}_{2} \\
\mathrm{MgCl}_{2} \\
\mathrm{MgCl}_{2}\end{array}$ & $\begin{array}{l}\overline{0.2} \\
0.5 \\
1.0 \\
2.0 \\
5.0 \\
1 \\
2 \\
5 \\
7.5 \\
10\end{array}$ & $\begin{array}{l}0 \\
0.1 \\
0.4 \\
1.2 \\
0.4 \\
0.2 \\
0.06 \\
0.3 \\
0.2 \\
0.03 \\
0.03\end{array}$ \\
\hline
\end{tabular}

Aliquots of phosphocellulose-purified sperm DNA polymerase were assayed in the presence of increasing concentrations of $\mathrm{K}_{3} \mathrm{PO}_{4}, \mathrm{MnCl}_{2}$ or $\mathrm{MgCl}_{2}$, using a dT $12-18 \cdot$ poly rA template. The incorporation of $\left[{ }^{3} \mathrm{H}\right] \mathrm{TPP}$ into acid-insoluble product is per $50 \mu \mathrm{l}$ reaction incubated at $37^{\circ} \mathrm{C}$ for $30 \mathrm{~min}$.

Table 3. Comparison of synthetic template-primer utilization by human sperm DNA polymerase and bovine DNA polymerase $\gamma$

\begin{tabular}{lcc}
\hline & \multicolumn{2}{c}{$\begin{array}{c}\text { Incorporation (pmol }\left[{ }^{3} \mathrm{H}\right] \mathrm{TTP} / \\
50 \mu \text { reaction) }\end{array}$} \\
\cline { 2 - 3 } Template primer & $\begin{array}{c}\text { Human sperm } \\
\text { polymerase }\end{array}$ & $\begin{array}{l}\text { Bovine DNA } \\
\text { polymerase } \gamma\end{array}$ \\
\hline $\mathrm{dT}_{12-18} \cdot$ poly rA & $2 \cdot 1$ & 2.0 \\
$\mathrm{dT}_{12-18} \cdot$ poly dA & 0.5 & 0.3 \\
poly $(\mathrm{dA}-\mathrm{dT})_{\mathrm{dG}_{12-18} \cdot \text { poly rC }}$ & 1.0 & 0.5 \\
$\mathrm{dT}_{10}$ & 0.014 & 0.014 \\
\end{tabular}

The sperm head DNA polymerase, purified through the glycerol gradient centrifugation step, and $0.25 \mu \mathrm{g}$ fetal calf liver DNA polymerase $\gamma$ were incubated with the various template primers plus the $\left[{ }^{3} \mathrm{H}\right] \mathrm{TTP}$ or $\left[{ }^{3} \mathrm{H}\right] \mathrm{dGTP}$ reaction mixture (see 'Materials and Methods') for $30 \mathrm{~min}$ at $37^{\circ} \mathrm{C}$ and the acid-insoluble radioactivity was determined. Duplicate analyses varied by less than $10 \%$. The $\mathrm{KCl}$ concentration in all reactions was $160 \mathrm{~mm}$.

to that found with DNA polymerase purified from isolated sperm nuclei (Text-fig. 2). Chromatography of this activity peak on phosphocellulose (Text-fig. $4 \mathrm{~b}$ ) yielded a major peak of $\mathrm{dT}_{12-18} \cdot$ poly $\mathrm{rA}$ activity eluting at $0.2 \mathrm{M}-\mathrm{KCl}$, similar to the elution profile of the enzyme isolated from sperm nuclei (Text-fig. 1b). 


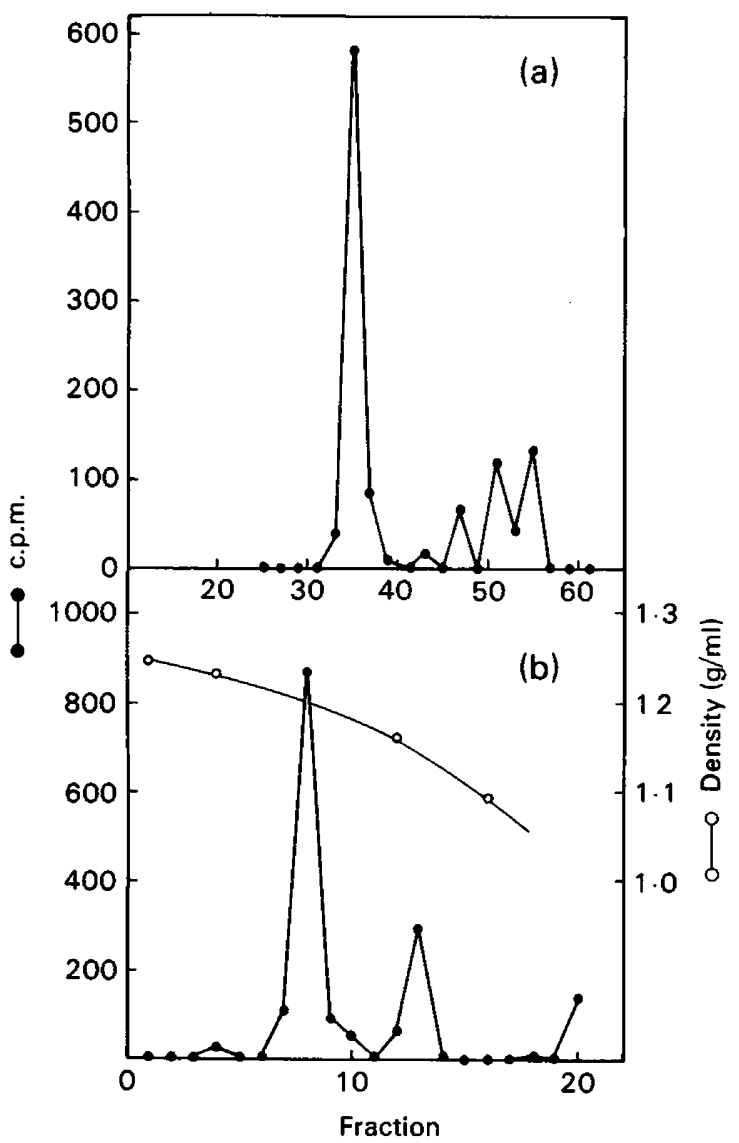

Text-fig. 3. Gel filtration and buoyant density of human sperm DNA-synthesizing complex. (a) A $165000 \mathrm{~g}$ pellet fraction isolated from enzyme-disrupted sperm heads was subjected to gel filtration on a $73 \times 1.2 \mathrm{~cm}$ Ultrogel AcA 34 column. The elution rate was $14 \mathrm{ml} / \mathrm{h} ; 1.2 \mathrm{ml}$ fractions were collected and $20 \mu \mathrm{l}$ aliquots were assayed using a $\mathrm{dT}_{12-18} \cdot$ poly rA template. (b) The pooled peak activity fractions from (a) were centrifuged to equilibrium in a $20 \mathrm{ml} 25-50 \%$ sucrose gradient; $0.9 \mathrm{ml}$ fractions were collected, density was determined from refractive indices, and $20 \mu \mathrm{l}$ aliquots were assayed for $\mathrm{dT}_{12-18} \cdot$ poly rA-templated activity.

\section{Discussion}

A major question arising from these studies is the origin of the sperm DNA polymerase. The improbability of semen-derived somatic cells, or mycoplasma or extracellular viruses as the source of the enzyme has already been discussed (Witkin et al., 1975). A possible sperm mitochondrial origin of the DNA polymerase is more difficult to rule out, especially in light of indications that the mitochondrial DNA polymerase is, in fact, DNA polymerase $\gamma$ (Bolden, Noy \& Weissbach, 1977; Beriazzoni, Scovassi \& Brun, 1977; Hübscher, Kuenzle \& Spadari, 1977). Bolden et al. (1977) demonstrated that $20 \%$ of the DNA polymerase $\gamma$ present in HeLa cells was associated with mitochondria, while the remainder was distributed between the nucleus and cytoplasm. If a similar situation exists for spermatozoa, then the intracellular localization of the enzyme reported here may have to be made solely by morphological criteria. Accordingly, the identification of an enzyme with identical properties both from detergent-treated purified 


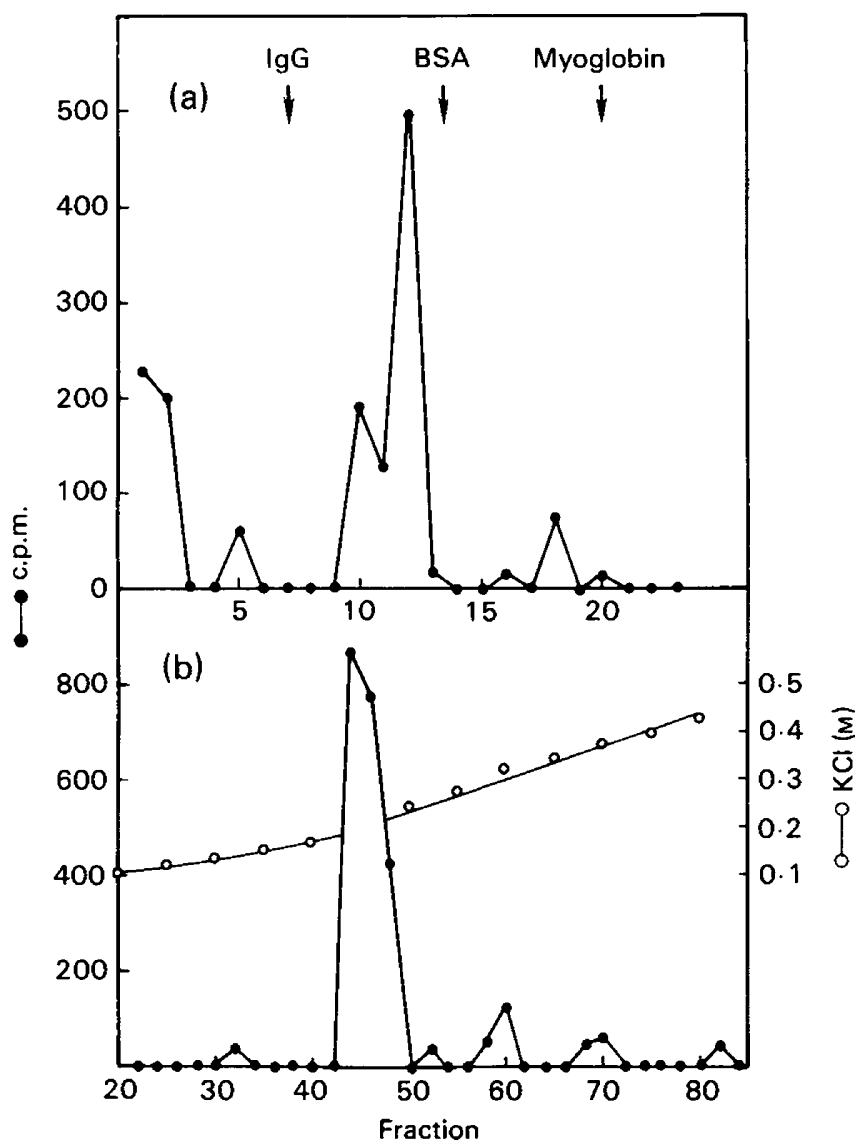

Text-fig. 4. Velocity centrifugation and phosphocellulose chromatography of DNA polymerase from the sperm DNA-synthesizing complex. (a) The peak activity fractions from the sucrose gradient (Text-fig. 3b) were concentrated by centrifugation and DNA polymerase was solubilized by the addition of $0.8 \mathrm{M}-\mathrm{KCl}, 0.5 \%$ Triton $\mathrm{X}-100$. The enzyme was sedimented in a 5 $\mathrm{ml} 15-30 \%$ sucrose gradient. Aliquots $(20 \mu \mathrm{l})$ of each $0.17 \mathrm{ml}$ fraction were assayed using a $\mathrm{dT}_{12-18}$ - poly $\mathrm{rA}$ template. The arrows mark the position of human immunoglobulin $\mathrm{G}$ (mol. wt $160000)$, bovine serum albumin $(68000)$ and sperm whale myoglobin $(17800)$ run in parallel gradients. (b) The pooled peak activity fractions from (a) were chromatographed on a $10 \times 0.9$ $\mathrm{cm}$ column. Elution was with $100 \mathrm{ml}$ of a $0.05-0.5 \mathrm{M}-\mathrm{KCl}$ gradient; $1.5 \mathrm{ml}$ fractions were collected and $20 \mu \mathrm{l}$ aliquots were assayed using a $\mathrm{dT}_{12-18} \cdot$ poly rA template.

sperm heads and from enzymically disrupted spermatozoa suggests a nuclear location for the DNA polymerase.

Although inconclusive, there are some biochemical data which suggests that the DNA polymerase described here is not from mitochondria. The inhibition of the sperm enzyme by $0 \cdot 1$ $M$-phosphate is consistent with similar properties of DNA polymerase $\gamma$ obtained from rat liver and HeLa cells; in contrast, the mitochondrial DNA polymerase $\gamma$ from rat liver and HeLa cells was unaffected by $0.1 \mathrm{M}$-phosphate (Bolden et al., 1977). In addition, the endogenous DNA polymerase reaction of mitochondria purified from rat liver (D'Agostino, Lowry \& Kalf, 1975) or chick embryo fibroblasts (D'Agostino \& Nass, 1976) was inhibited by dithiothreitol or B-mercaptoethanol, while dithiothreitol was non-inhibitory to DNA synthesis by the sperm DNA-synthesizing complex (unpublished observations). 
Our bovine DNA polymerase $\gamma$ preparation was present in a $0.2 \mathrm{mg} / \mathrm{ml}$ solution purported by the supplier to contain 2 units of activity $/ \mathrm{ml} ; 1$ unit is defined as the polymerization of $1 \mathrm{nmol}$ dTTP by incubation at $37^{\circ} \mathrm{C}$ for $60 \mathrm{~min}$ in the presence of $\mathrm{dT}_{12-18} \cdot$ poly rA. In the experiment described in Table 3,1.25 $\mu \mathrm{l}$ of this DNA polymerase $\gamma$-containing solution catalysed the incorporation of 2 pmol dTTP (0.004 units) in a 30-min reaction. This is slightly better than the expected calculated value of 0.0025 enzyme units per 2 pmol dTMP polymerized. Our assay system is thus shown to be efficient for measuring this enzyme activity and a minimum estimate (assuming $100 \%$ recovery at each stage of purification) for the number of DNA polymerase $\gamma$-equivalents/spermatozoon can be calculated. An aliquot of the glycerol gradient-purified sperm DNA polymerase from approximately $2 \times 10^{9}$ spermatozoa also possessed 0.04 units (2 pmol) of activity (Table 3), i.e. $5.8 \times 10^{-10}$ units/spermatozoon or $1.2 \times 10^{-1}$ units/ejaculate. Similar calculations for DNA polymerase $\gamma$, utilizing the data of Bolden et al. (1967) and estimating $3 \times 10^{8}$ cells or $3 \times 10^{11}$ mitochondria (A. Bendich, personal communication), give an estimate for rat liver of approximately $6 \times 10^{-10}$ units of enzyme in the non-mitochondrial fraction per cell.

The results of Bolden et al. (1977) also show that there are approximately $2.8 \times 10^{-14}$ units of enzyme/mitochondrion. If a human spermatozoon contains 30 mitochondria (Lung, 1974) and if our head preparations were contaminated with mitochondria at a level of $2 \%$, then there would be $4 \times 10^{6}$ tails or $1.2 \times 10^{8}$ mitochondria in the head preparation per ejaculate. If mitochondrial DNA polymerase $\gamma$ activity was similar in spermatozoa and in rat liver cells, $3 \cdot 3$ $\times 10^{-6}$ units of DNA polymerase $\gamma$ activity/ejaculate could be expected. However, our minimum estimate for the enzyme activity in our sperm preparation was over 100000 times greater than this value (see above), and the majority, at least, of the sperm DNA polymerase is not therefore of mitochondrial origin.

The DNA polymerase obtained by two fractionation procedures following rupture of the sperm nucleus appears to be the enzyme present in the DNA-synthesizing complex (Witkin et al., 1975; Witkin \& Bendich, 1977; Witkin et al., 1977a). DNA polymerase $\gamma$ has been found associated with other endogenous DNA-synthesizing components from human lymphoid cells (Yoshida \& Cavalieri, 1977), rat brain (Witkin \& Schumaker, 1977) and adenovirus-infected cells (Ito, Arens \& Green, 1975; Brison, Kendinger \& Wilhelm, 1977) and it may therefore be involved in specific DNA synthesis. The retention of this enzyme by the highly specialized male gametes, which have lost cytoplasm and achieved a condensed nucleus during spermatogenesis, suggests that the enzyme might have a function after fertilization. Further characterization of the sperm DNA-synthesizing complex might offer clues as to the role, if any, these enzymes play in DNA synthesis during embryogenesis and, by inference, in DNA replication in general.

This study was initiated in the laboratory of the late Dr Aaron Bendich. His suggestions and criticisms are gratefully acknowledged. Ms Cynthia A. Brown provided outstanding technical assistance. The study was supported by NIH grant 1 R01 HD 10826-01 and grant GA PS 7905 from the Rockefeller Foundation.

\section{References}

Bendich, A., Borenfreund, E., Witkin, S.S., Beju, D. \& Higgins, P.J. (1976) Information transfer and sperm uptake by mammalian somatic cells. Prog. Nucleic Acid Res. Mol. Biol. 17, 43-75.

Beriazzoni, U., Scovassi, A. \& Brun, G.M. (1977) Chick-embryo DNA polymerase $\gamma$. Identity of $\gamma$-polymerases purified from nuclei and mitochondria. Eur.J. Biochem. 81, 237-248.
Bolden, A., Noy, G.P. \& Weissbach, A. (1977) DNA polymerase of mitochondria is a $\gamma$-polymerase. $J$. biol. Chem. 252, 3351-3356.

Brison, O., Kedinger, C. \& Wilhelm, J. (1977) Enzymatic properties of viral replication complexes isolated from adenovirus type $\mathrm{z}$-infected $\mathrm{HeLa}$ cell nuclei. J. Virol. 24, 423-425.

Burgess, R.R. (1969) A new method for the large scale 
purification of Escherichia coli deoxyribonucleic acid-dependent ribonucleic acid polymerase. $J$. biol. Chem. 244, 6160-6167.

Calvin, H.I. (1976) Isolation and subfractionation of mammalian sperm heads and tails. In Methods in Cell Biology, Vol. 13, pp. 85-104. Ed. D. M. Prescott. Academic Press, New York.

D'Agostino, M.A. \& Nass, M.M.K. (1976) Specific changes in the synthesis of mitochondrial DNA in chick embryo fibroblasts transformed by rous sarcoma viruses. J. Cell Biol. 71, 781-794.

D'Agostino, M.A., Lowry, K.M. \& Kalf, G.G. (1975) DNA biosynthesis in rat liver mitochondria. Inhibition by sulfhydryl compounds and stimulation by cytoplasmic proteins. Arch. Biochem. Biophys. 166, 400-416.

Gall, W.E., Millette, C.F. \& Edelman, G.M. (1975) Chemical dissection of mammalian spermatozoa. Acta endocr., Copenh., Suppl. 194, 154-172.

Higgins, P.J., Witkin, S.S. \& Bendich, A. (1978) Inhibition of human seminal fluid DNA polymerase by an IgG fraction of seminal plasma from vasectomized men. J. Reprod. Fert. 54, 97-102.

Hübscher, U., Kuenzle, C.C. \& Spadari, S. (1977) Identity of DNA polymerase $\gamma$ from synaptosomal mitochondria and rat-brain nuclei. Eur. J. Biochem. 81, 249-258.

Ito, K., Arens, M. \& Green, M. (1975) Isolation of DNA polymerase $\gamma$ from an adenovirus 2 DNA replication complex. J. Virol. 15, 1507-1510.

Lung, B. (1974) Architecture of mammalian sperm: analysis by quantitative electron microscopy. $A d v$. Cell Mol. Biol. 3, 73-133.

Martin, R.G. \& Ames, B.N. (1961) A method for determining the sedimentation behaviour of enzymes: application to protein mixtures. $J$. biol. Chem. 236 , 1372-1379.

Witkin, S.S. \& Bendich, A. (1977) DNA synthesizing activity in normal human sperm: location and characterization of the endogenous reaction. Expl Cell Res. 106, 47-54.

Witkin, S.S. \& Higgins, P.J. (1978) Effects of vasectomy and antisperm antibodies on human seminal fluid DNA polymerase activity. Fert. Steril, 29, 314-319.

Witkin, S.S. \& Schumaker, H.M. (1977) A particulate DNA polymerase activity. Fert. Steril. 29, 314-319. Biochem. Biophys. Res. Commun. 75, 568-575.

Witkin, S.S., Korngold, G.C. \& Bendich, A. (1975) Ribonuclease-sensitive DNA-synthesizing complex in human sperm heads and seminal fluid. Proc. natn. Acad. Sci. U.S.A. 72, 3295-3299.

Witkin, S.S., Traganos, F. \& Bendich, A. (1977a) Isolation of a nuclear DNA synthesizing complex from human sperm. Biochem. Biophys. Res. Commun. 77, 1404-1410.

Witkin, S.S., Evenson, D.P. \& Bendich, A. (1977b) Chromatin organization and the existence of a chromatin-associated DNA generating system in human sperm. In Molecular Biology of the Mammalian Genetic Apparatus, Part A, pp. 345-354. Ed. P. O. P. Ts'o. Elsevier/North Holland Biomedical Press, Amsterdam

Witkin, S.S., Higgins, P.J. \& Bendich, A. (1978) Inhibition of viral reverse transcriptase and human sperm DNA polymerase by anti-sperm antibodies. Clin. exp. Immun. 33, 244-251.

Yoshida, S. \& Cavalieri, L.F. (1977) Characterization of a DNA polymerase associated with an endogenous DNA-synthesizing complex isolated from human lymphoid cells. Biochim. Biophys. Acta 475, 42-53.

Received 29 October 1979 